\section{REFERENCES}

1. The Joint Commission. Performance measurement initiatives - core measure set information. Available at: http://www.jointcommission.org/ PerformanceMeasurement/PerformanceMeasurement/default.htm Accessed March 13, 2009.
2. Catalano K, Fickenscher K. Complying with the 2008 national patient safety goals. AORN J. 2008;87(3):547-56.

3. The Joint Commission. National patient safety goals. Available at: http:// www.jointcommission.org/PatientSafety/NationalPatientSafetyGoals/. Accessed April 24, 2009.

\title{
Correction - Author Disclosures
}

A Letter to the Editor written by C. Venkata S. Ram and Thomas Giles included an inaccurate statement of Disclosures. ${ }^{1}$ C. Venkata S. Ram, MD, MACP, FACC, reports the receipt of compensation including speaking fees related to serving on speakers' bureaus for Advanced Health Media, COGENIX, and GENESIS, which conduct educational programs for companies that manufacture pharmaceuticals and medical devices. Thomas Giles, MD, FACC, reports the receipt of grants for clinical research from AstraZeneca, Amgen, Abbott, Novartis, and National Institutes of Health, as well as grants for educational activities from AstraZeneca, Novartis, Boehringer-Ingelheim, and Sankyo/Forest. Dr. Giles also discloses that he has served as an advisor or consultant for Novartis, Pfizer, Boehringer-Ingelheim, Bristol-Myers Squibb, and Sankyo/Forest.

\section{REFERENCE}

1. Ram CVS, Giles T. Need to revisit step therapy for ARBs (letter). J Manag Care Pharm. 2007;13(6):528-29. Available at: http://www.amcp.org/data/ jmcp/pages\%20528-31.pdf 